\title{
State Considerations in Understanding the Costs of Elections
}

\author{
Virginia Vander Roest
}

\begin{abstract}
Effective training is critical for election administrators with limited resources. The State can be valuable in providing these services. Care should be taken to ensure the training and associated materials are available in a variety of formats and materials as the needs of election administrators vary across local jurisdictions and counties.
\end{abstract}

Keywords Training $\bullet$ Online resources $\bullet$ Cost

Unbeknownst to me, I started my career as a college student working part-time as a voter registration clerk for a medium-sized city in the State of Michigan in 1999. I was working on my Bachelor's Degree in Public Administration and quickly found the work was engaging, interesting, and incredibly important. My employer valued education and training and allowed me to pursue the Election Center and Auburn University's Professional Education Program certification in voter registration and

V. Vander Roest $(\bowtie)$

Bureau of Elections, Lansing, MI, USA

e-mail: vanderroestv@michigan.gov

(C) The Author(s) 2019

M. Brown et al. (eds.), The Future of Election Administration, Elections, Voting, Technology, https://doi.org/10.1007/978-3-030-18541-1_15 
election administration (Certified Elections Registration Administrator or CERA). I steadily worked my way up through the positions of Election Specialist and Election Director over 12 years. Those initial 12 years were during times of great change in the field of election administration.

The structure of Michigan elections varies greatly from that of most states, which typically operate elections through a county office. Elections in Michigan are run at the township and city level with the county playing a small role as well. Fun fact-prior to 2005 , school district administrators and villages were also responsible for conducting their own elections. There are 1520 cities and townships in the State of Michigan and 83 counties equating to just over 1600 entities and individuals tasked with election administration for their jurisdiction; 28 jurisdictions have more than 40,000 registered voters and 1369 have under 10,000 registered voters with 857 of those under 2000 registered voters. The average jurisdiction size has 4892 registered voters.

As one can imagine this diversity and decentralization leads to a great challenge in ensuring elections are conducted properly across the State. Becoming a CERA (only the second in the State of Michigan) and working on various Election Center task forces provided me with powerful knowledge and resources that very few had access to. As I participated in education programs around the state, that became more and more apparent. This is not to say that other election administrators in the state were not professional and overwhelmingly committed to conducting elections correctly. Election administrators had the desire to learn more, but the resources are simply not there. Out-of-state travel for small jurisdictions is not a budget item and for those with larger budgets, funds allocated for training and education are often split among all of the other responsibilities of the local clerk.

In 2011, I began working for the State of Michigan Bureau of Elections as an Election Specialist concentrating on the training of local election administrators (also known as clerks) and, in 2017, I became the Training and Communications Manager. The State of Michigan has 3 employees who focus on training of 1600 election administrators and staff $(\sim 3400$ in total) as well as assisting them in properly training their 30,000 election inspectors (known as poll workers in many places). The Bureau of Elections training staff are not just the primary resource for information-in many cases we are the only resource.

Michigan election law has required an initial accreditation training for all local clerks for many years. The Bureau of Elections has offered a two-day 
in-person class to comply with the requirement. This was a good start, but an imperfect solution. The majority of clerks attended the two-day class in order to comply, but that's where the effect of the legal requirement ended. In theory, someone could complete the initial training and never attend another training session even 20 years down the road. In 2012, the Michigan legislature mandated continuing education for all clerks.

Training and educating clerks who have very different backgrounds, office hours, and levels of professionalism is incredibly difficult. The complexity of election law is one factor. It's certainly important to ensure that everyone understands every aspect of election law but, in many cases, the nuances of election law are rarely encountered. What is incredibly relevant in one jurisdiction may be a total anomaly in another. Many of the election administrators in Michigan work part-time and a large number hold other jobs, even full-time jobs. Their access to training can be dependent on their other employer allowing them the time off.

In 2013, the Michigan Bureau of Elections launched an online training system (Election eLearning Center) to comply with the continuing education requirements of the legislature and the reporting requirements of our auditors. These administrative requirements also led to benefits of being able to more regularly reach our audience and provide supplemental training at the relevant times.

Having an online training system has allowed us to enhance all of our training in different ways. The software to create videos and online courses is in house; we aren't reliant on a third-party vendor to generate our content. The videos are, of course, used in the online training system but they are also used to break up lectures during in-person training. These new resources have given every election administrator's office new tools. We've found that having videos available allows an election administrator flexibility. They can use them to reinforce the training they've previously attended. They can use them to train new staff members that perhaps don't need the full initial accreditation program. They may find a need to show administrators or poll workers a specific part of the process. It's hard to measure the value as we are still finding new ways in which these new materials are being utilized around the state.

However, having an online learning system has not replaced our inperson training components and there are no plans to do so in the future. Beyond the initial accreditation program, the Michigan Bureau of Elections provides several other in-person options. These classes were offered before the continuing education requirement and some are now required components of continuing education every two years. 
The first required in-person class is for county clerks and clerks of jurisdictions with more than 10,000 registered voters. Those clerks are responsible for training poll workers. Before the even-numbered year begins, we conduct this in-person class to give them an overview of what they should focus on in their poll worker training programs and we provide them with new tools to help make their training more effective. Every two years, we add to our catalog of poll worker training videos and in the last few years, we have supplied a new hands-on training activity. The hands-on activities are designed so the clerk can easily slide it into their training without creating it themselves.

The local units of government have faced many budget cuts over the last ten years. Most offices are operating with fewer staff members than they had ten years ago. This equates to fewer people doing much more work and often with reduced resources. Offices may want to create videos or hands-on activities for their poll workers but the reality is they just don't have the time or technical staff available for such projects.

The second in-person required class is called Election Cycle Preparation. In the late winter/early spring of every even year, we have three trainers who visit all 83 counties to provide a 2.5 -hour training session on preparing for even-year elections. It is generally a high-level overview of as many topics as we can cover, with highlights relaying the messages of change, mistake, or improvement. We use our post-election audit process (performance based) to signify areas of deficiency and to identify effects of known changes that occurred since the last even-number year election cycle.

This 2.5-hour training session may be the only time we see a local clerk in person over a two-year period, and it has tremendous value for all involved. Not only do the trainers have the opportunity to clarify topics that have been communicated to them, but the trainers learn where the sticking points are so that future communications and trainings can focus on those items that are most confusing. It's also beneficial for the trainers (who are often times the same people that answer phone calls when back in the office) to hear the realities of those who are the front lines of our process. The resources available from county to county, jurisdiction to jurisdiction vary greatly. A trainer may be in an affluent county in the morning and then travel to a struggling neighboring county in the afternoon. Even though the material that is presented is the same, the conversations at these trainings can be vastly different. Our clerks had concerns that the online system would replace our in-person components. Instead, the reality is that the online resources have allowed us to make those inperson sessions much more effective. 
Our election administrators are overwhelmed with priorities. As I've traveled around the state (and the country) one thing still remains the same-those in these positions want to serve and protect democracy. They want to do the best job that they are able to do with the resources they have. And they do just that with very little of those resources. The ability of the state to provide good, effective, and timely training is critical. Even in jurisdictions and counties where there are more resources available, the state trainers and their resources serve as one less thing that local offices need to develop and deliver. Most importantly, the state training initiative provides a consistent message across all jurisdictions.

The training approach in Michigan has expanded and new methods have been implemented since I first began in elections. Laws have changed as well, and become more complicated. Public and media scrutiny of elections is very high. Training has become more detailed-there is more to know-and the same attention to every detail is still required. These pressures can shift the tone in training from one of assistance and problem solving toward a focus on policing and compliance. There is intrinsic value in having walked in the shoes of those that you train. It has provided me with credibility and trust among the election administrators around the state; although their experiences may not be identical to mine, we have a common understanding of what is supposed to happen. This advances the training conversations and moves everyone closer to addressing training issues that improve the process.

Open Access This chapter is licensed under the terms of the Creative Commons Attribution 4.0 International License (http://creativecommons.org/licenses/ by $/ 4.0 /)$, which permits use, sharing, adaptation, distribution and reproduction in any medium or format, as long as you give appropriate credit to the original author(s) and the source, provide a link to the Creative Commons licence and indicate if changes were made.

The images or other third party material in this chapter are included in the chapter's Creative Commons licence, unless indicated otherwise in a credit line to the material. If material is not included in the chapter's Creative Commons licence and your intended use is not permitted by statutory regulation or exceeds the permitted use, you will need to obtain permission directly from the copyright holder.

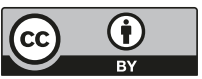

